\title{
PENGARUH KOMBINASI TEPUNG BEKATUL DAN TEPUNG MENIR C4 TERHADAP BEBERAPA KOMPONEN MUTU COOKIES
}

\section{[Effect of Combination C4 Rice Bran Flour and Grain of Rice Flour on the Quality Component of Cookies]}

\author{
Mira Idora*, Agustono Prarudiyanto dan Ahmad Alamsyah \\ Program Studi Ilmu dan Teknologi Pangan, Fakultas Teknologi Pangan dan Agroindiustri, Universitas Mataram \\ *email: MiraIdora75@gmail.com
}

Diterima 4 Oktober 2017/ Disetujui 8 November 2017

\begin{abstract}
The purpose of this research was to know the best combination of rice bran and grains of rice flour that cloud be seen from some quality components of cookies include moisture, protein and ash content, organoleptic quality such as flavour referring to National Indonesian Standard (SNI). This research use Compoletely Randomized Block Design, consist of six treatments (100\% wheat flour, 30\% rice bran: $70 \%$ grains of rice flour, $40 \%$ rice bran: $60 \%$ grains of rice flour, $50 \%$ rice bran: $50 \%$ grains of rice flour, $60 \%$ rice bran: $40 \%$ grains of rice flour, $70 \%$ rice bran: $30 \%$ grains of rice flour) with three replications. The data were analyzed using Analysis of Variance diversity at $5 \%$ significance level using Co-Stat Software and tested further using Orthogonal Polynomials test if there was real difference. The results showed that the proportion of rice bran and grain of rice flour had significant effect on taste, aroma, texture and color (hedonic and scoring), protein and ash content, but not significantly different to moisture of cookies. The results of this study also showed that the proportion of white rice brain and grains of rice flour which produced cookies with the best quality in accordance with SNI quality requirements was the treatment of $30 \%$ rice bran: $70 \%$ grains of rice flour $(4.8008 \%$ moisture, $6.0461 \%$ protein content and $1.9274 \%$ ash content, with flavor, aroma, texture and color which was very favored by the panelists where cookies with yellowish brown color and slightly crunchy texture).
\end{abstract}

Keywords:cookies, grains of rice flour, rice bran flour, white rice.

\begin{abstract}
ABSTRAK
Tujuan penelitian ini yaitu untuk mengetahui kombinasi terbaik dari tepung bekatul dan tepung menirterbaik dilihat dari beberapa komponen mutu cookies meliputi kadarair, kadar protein, kadar abu dan mutu organoleptik seperti bau, rasa, aroma dan tekstur yang mengacu pada Standar Nasional Indonesia (SNI). Penelitian ini menggunakan Rancangan Acak Kelompok (RAK), terdiri dari enam perlakuan (Tepung terigu 100\%, Tepung Bekatul $30 \%$ : Tepung Menir $70 \%$, Tepung Bekatul $40 \%$ : Tepung Menir 60\%, Tepung Bekatul 50\% : Tepung Menir 50\%, Tepung Bekatul $60 \%$ : Tepung Menir 40\% dan Tepung Bekatul 70\%: Tepung Menir 30\%) dengan tiga kali ulangan. Data hasil penelitian dianalisis menggunakan analisis keragaman ANOVA (Analysis of Variance) pada taraf $5 \%$ menggunakan Software Co-Stat dan diuji lanjut menggunakan uji lanjut Polinomial Ortogonal jika terdapat beda nyata. Hasil penelitian menunjukkan bahwa proporsi tepung bekatul dan tepung menir memberikan pengaruh yang berbeda nyata terhadap parameter rasa, aroma, tektur dan warna (Hedonic dan Scoring), kadar protein dan kadar abu, namun tidak berbeda nyata terhadap kadar air cookies. Hasil penelitian ini juga menunjukkan bahwa proporsi tepung bekatul dan tepung menir yang menghasilkan cookies dengan mutu terbaik yang sesuai dengan syarat mutu SNI adalah perlakuan tepung bekatul $30 \%$ : tepung menir $70 \%$ (kadar air 4,8008\%, kadar protein $6,0461 \%$ dan kadar abu 1,9274\%, dengan rasa, aroma, tektur dan warna sangat disukai panelis dimana cookies berwarnacokelat kekuningan dan tekstur agak renyah).
\end{abstract}

Kata kunci:beras putih, cookies, tepung bekatul, tepung menir

\section{PENDAHULUAN}

Kue kering (cookies) merupakan biskuit yangberbahan dasar tepung terigu.Keunggulan dari tepung terigu yaitu kemampuannya untuk membentuk gluten pada saat diberi air.Sifat elastis gluten pada adonan menyebabkan kue tidak mudah rusak ketika dicetak.Indonesia saat ini menduduki peringkat kedua importir gandum terbesar di dunia (Mulyani, Djajati dan Rahayu, 2015).Berdasarkan data Badan Pusat Statistik (BPS) bahwa nilai impor gandum secara keseluruhan di tahun 2016 lalu mencapai 10,5 juta ton tercatat senilai US\$ 2,4 miliar sedangkan nilai impor tepung terigu mencapai 148,2 ton senilai US\$ 42,5 juta.

Jika keadaan ini dibiarkan, ketergantungan pangan dari luar negeri dapat meningkatkan pengeluaran devisa negara. 
Oleh karena itu perlu adanya upaya mengurangi ketergantungan terhadap penggunaan tepung terigu.Salah satu cara untuk mengurangi kebutuhan tepung terigu pada pembuatan cookies yaitu dengan menggantikan sebagian atau seluruh tepung terigu pada pembuatan cookies yaitu dengan tepung lain misalnya tepung bekatul dan tepung menir. Sebagaimana yang kita ketahui bahawa pemanfaatan hasil samping berupa bekatul dan menir tersebut masih terbatas. Hasil sampingan seperti bekatul dan menir mempunyai nilai gizi, nilai guna dan ekonomi yang baik apabila ditangani dengan benar sehingga dapat meningkatkan nilai tambahnya.Dengan memanfaatkanya dalam pembuatan cookies maka hal ini merupakan salah satu upaya dalam memanfaatkan limbah bekatul dan limbah beras menir serta penganekaragaman produk cookies.

Bekatul merupakan limbah dalam proses penggilingan gabah dan penyosohan beras. Bagian ini memang tidak diinginkan terikut pada beras karena selain memperpendek umur simpan beras akibat ketengikan yang ditimbulkannya, juga memperburuk penampilan beras karena warna kecoklatan yang dimilikinya. Namun sesungguhnya pada bekatul beras kaya akanzat-zat gizi yang bermanfaat bagi kesehatan manusia. Di dalam bekatul dapat ditemukan serat pangan, asam lemak tidak jenuh, sterol, protein dan juga mineral (Astawan dan Febrinda, 2010).Selain itu Bekatul juga merupakan bahan pangan yang bersifat hipoalergenik dan merupakan sumber serat pangan (dietary fiber) yang baik (Mulyani dkk, 2015).

Menir merupakan bagian beras yang hancur. Menir adalah beras patah yang ukurannya lebih kecil dari 0,2 bagian beras utuh atau butir beras patah yang lolos ayakan dengan ukuran 1,7 mm (Kadarisman, 1986). Menurut Widowati (2001) dalam proses penggilingan padi menjadi beras giling, diperoleh hasil samping berupa (1) sekam $(15-20 \%)$, yaitu bagian pembungkus atau kulit luar biji, (2) bekatul (8-12\%) yang merupakan kulit ari, dihasilkan dari proses penyosohan, dan (3) menir $( \pm 5 \%)$ merupakan bagian beras yang hancur. Apabila produksi gabah kering giling nasional 49,8 juta/tahun (pada tahun 1996), maka akan diperoleh sekam 7,5-10 juta ton, bekatul 4-6 juta ton, dan menir 2,5 juta ton. Selama ini pemanfaatan menir belum optimal.Pada umumnya masyarakat menggunakan menir hanya sebagai pakan ternak. Hal tersebut dikarenakan bentuk dan penampakannya yang berupa patahan sehingga kurang menarik minat masyarakat untuk mengkonsumsinya.

\section{METODOLOGI}

\section{Bahan dan Alat}

Bahan-bahan yang digunakan dalam penelitian ini adalah tepung bekatuldan menir C4,tepung terigumerkSegitiga Biru, gula tepungmerkKupu-kupu, margarinemerk Filma, telur ayam,baking powder merk R\&W,garam beryodium merk Karapan Sapi dan vanili merk R\&W.

Adapun bahan kimia dan perlatanyang digunakan dalam penelitian ini adalahasam sulfat, $\mathrm{H}_{2} \mathrm{SO}_{4}$ pekat bebas nitrogen,larutan katalis tembaga, $\mathrm{CuSO}_{4} \cdot 5 \mathrm{H}_{2} \mathrm{O}$ bebas nitrogen $0,05 \mathrm{~g} / \mathrm{mL} \mathrm{H}_{2} \mathrm{O}$, katalis selen, campuran $4 \mathrm{~g}$ serbuk $\mathrm{SeO}_{2}, 150 \mathrm{~g} \mathrm{~K}_{2} \mathrm{SO}_{4}$ atau $\mathrm{Na}_{2} \mathrm{SO}_{4}$ dan $30 \mathrm{~g} \mathrm{CuSO}_{4} .5 \mathrm{H}_{2} \mathrm{O}$, kalium sulfat, $\mathrm{K}_{2} \mathrm{SO}_{4}$ bebas nitrogen, batu didih, indikator Methyl Red (MR)/Bromocresol Green (BCG), larutan asam borat, $\mathrm{H}_{3} \mathrm{BO}_{3}, 4 \%$, larutan natrium hidroksida $\mathrm{NaOH} 30 \%$, larutan indikator fenolftalein (PP) $1 \%$ dan larutan asam klorida, $\mathrm{HCl} 0,01 \mathrm{~N}$, ayakan 80 mesh merk Retsch, stopwatch, mixer merk Miyako HM-620, roll pin, cetakan cookies, drying oven merk Memmert tipe UNB 400, timbangan analitik merk Kern/ABJ 220 4m, drying oven merk Memmert tipe UNB 800, desikator, cawan porselin, labu Kjedahl, alat destilasi Kjedahl, alat penyuling dan kelengkapannya, pemanas listrik, labu ukur, gelas beaker, buret $10 \mathrm{~mL}$ dan batu didih.

\section{Tahapan Penelitian}

Penelitian ini memiliki dua tahapan pengerjaan diantaranya yaitu tahapan pertamameliputi proses pembuatan tepung bekatul dan tepung menir. Tahapan kedua yakni proses pembuatan cookies.

\section{Pembuatan Tepung Bekatul}

Bekatul C4 yang akan digunakan ditimbang sebanyak 500g.Kemudian disortasi dengan menggunakan ayakan 60 mesh, dan digiling dengan menggunakan blender. Kemudian bekatul dikeringkan dengan ovenselama 15 menit pada suhu $100^{\circ} \mathrm{C}$.Kemudian diayak menggunakan ayakan 80 mesh.

\section{Tepung Menir}

Menir C4yang akan digunakan ditimbang sebanyak $500 \mathrm{~g}$.Kemudian disortasi dengan ditampimenggunakan alat penampi dan digiling menggunakan mesin huller 
tepung. Kemudian diayak dengan menggunakan ayakan 80 mesh.

\section{Pembuatan Cookies}

Ditimbang semua bahan baku meliputi tepung bekatul 30\% (48 g); $40 \%$ (64 g); $50 \%$ $(80 \mathrm{~g}) ; 60 \%(96 \mathrm{~g}) ; 70 \%(112 \mathrm{~g})$, tepung menir $70 \%(112 \mathrm{~g}) ; 60 \%(96 \mathrm{~g}) ; 50 \%(80 \mathrm{~g}) ;$ $40 \%$ (64 g); $30 \%$ (48 g), tepung terigu $100 \%$ $(116 \mathrm{~g})$, gula tepung $100 \mathrm{~g}$, margarine 35 g,telur $50 \mathrm{~g}$, baking powder $1 \mathrm{~g}$, garam $0,5 \mathrm{~g}$ dan vanili $0,5 \mathrm{~g}$. Proses pertama adalah dengan mencampurkan bahan margarine,gula tepung, telur ayam, garam dan vanili menggunakan mixer dengan kecepatan putaran tinggi selama 7 menit. Selanjutnya ditambahkan tepung bekatuldan tepung menir sesuai dengan perlakuan yang telah ditentukan. Pencampuran dilakukan dengan cara manual menggunakan tangan hingga adonan tercampur rata dan kalis.Setelah pencampuran, kemudian adonan dicetak dengan ketebalan $5 \mathrm{~mm}$, kemudian diletakkan dalam loyang yang telah disiapkan.Cetakan cookies yang sudah jadi kemudian dipanggan dengan oven pada suhu $180^{\circ} \mathrm{C}$ selama 15 menit.

\section{Parameter Penelitian}

Parameter yang diamati dalam penelitian meliputi sifat kimia dan organoleptik. Parameter sifat kimia meliputi kadarair dengan metode termogravimetri, kadar protein dengan metode Kjedhal dan kadar abu dengan metode pengabuan kering (Standar Nasional Indonesia, 2011). Sedangkan parameter organoleptik meliputi rasa, warna, tekstur dan aroma dilakukan menggunakan uji Hedonic dan uji Scoring (Rahayu, 1998).

\section{Rancangan Percobaan dan Analisis Data}

Metode yang digunakan pada penelitian adalah metode eksperimental dengan percobaan di laboratorium. Rancangan percobaan yang digunakan dalam penelitian adalah Rancangan Acak Kelompok (RAK) dengan percobaan faktor tunggal yaitu kombinasi tepung bekatul beras putih dengantepung menirdan penggunaan tepung terigu $100 \%$ (A) sebagai kontrol yaitu:

$\mathrm{a}_{0}=$ Tepung terigu $100 \%$ (kontrol)

$a_{1}=$ Tepung bekatul $30 \%+$ Tepung menir $70 \%$

$a_{2}=$ Tepung bekatul $40 \%+$ Tepung menir $60 \%$

$\mathrm{a}_{3}=$ Tepung bekatul $50 \%+$ Tepung menir $50 \%$

$\mathrm{a}_{4}=$ Tepung bekatul $60 \%+$ Tepung menir $40 \%$

$a_{5}=$ Tepung bekatul $70 \%+$ Tepung menir $30 \%$
Masing-masing perlakuan diulang sebanyak 3 kali ulangan, sehingga diperoleh 18 unit sampel. Data hasil pengamatan kimia dan organoleptik dianalisis dengan analisis keragaman ANOVA (Analysis of Varience) pada taraf nyata $5 \%$. Dengan menggunakan Software Co-Stat. Bila terdapat beda nyata dilanjutkan dengan uji Ortogonal Polinomial untuk parameter kimia sedangkan untuk parameter organoleptik menggunakan uji Beda Nyata Jujur (BNJ)pada taraf nyata 5\% (Hanafiah, 2010).

\section{HASIL DAN PEMBAHASAN}

\section{Hasil Analisis Bahan Baku}

Pada penelitian ini dilakukan analisis kimia berupa kadar air, kadar protein dan kadar abu terhadap bahan baku yakni tepung bekatul, tepung menir dan tepung terigu. Hasil analisis kimia bahan baku tepung dan cookies masing-masing dapat dilihat pada Tabel 1 dan 2.

Tabel 1. Hasil Pengamatan Purata Analisis Kimia Bahan Baku Tepung

\begin{tabular}{lccc}
\hline \multirow{2}{*}{ Parameter(\%) } & \multicolumn{2}{c}{ Bahan Baku Tepung } \\
\cline { 2 - 4 } & Terigu & Menir & Bekatul \\
\hline Kadar Air & 12,3586 & 11,0789 & 5,2477 \\
Kadar Protein & 8,1646 & 5,8218 & 11,6685 \\
Kadar Abu & 0,8928 & 0,7311 & 9,5545 \\
\hline
\end{tabular}

Tabel 2. Hasil Pengamatan Purata Analisis Kimia Cookies

\begin{tabular}{cccc}
\hline \multirow{2}{*}{ Perlakuan } & \multicolumn{3}{c}{ Parameter (\%) } \\
\cline { 2 - 4 } & $\begin{array}{c}\text { Kadar } \\
\text { Air }\end{array}$ & $\begin{array}{c}\text { Kadar } \\
\text { Protein }\end{array}$ & $\begin{array}{c}\text { Kadar } \\
\text { Abu }\end{array}$ \\
\hline a0 & 4,2361 & 6,5276 & 0,9677 \\
a1 & 4,8008 & 6,0461 & 1,9274 \\
a2 & 3,6749 & 6,2343 & 4,1393 \\
a2 & 3,3603 & 6,4671 & 5,1577 \\
a4 & 3,1143 & 6,7557 & 8,2093 \\
a5 & 3,0614 & 7,0415 & 9,5190 \\
\hline
\end{tabular}

Keterangan :

$\mathrm{a}=$ penambahan tepung bekatul dan tepung menir kecuali a0

$\mathrm{a} 0=$ tepung terigu $100 \%$ (Kontrol)

$$
\begin{array}{ll}
\text { a1 }=30 \%: 70 \% & \text { a2 }=40 \%: 60 \% \\
\text { a3 }=50 \%: 50 \% & \text { a4 }=60 \%: 40 \% \\
\text { a5 }=70 \%: 30 \% &
\end{array}
$$

\section{Kadar Air}

Berdasarkan Tabel2dapat dilihat bahwa proporsi penggunaan tepung menir dan tepung bekatul memberikan pengaruh yang non signifikan (tidak berbeda nyata) terhadap kadar air cookies. Oleh karena itu tidak dilakukan uji lanjut polinomial ortogonal terhadap kadar air cookies. Hubungan antara 
proporsi penggunaan tepung menir dan tepung bekatul terhadap kadar air cookiesdapat dilihat pada Gambar 1.

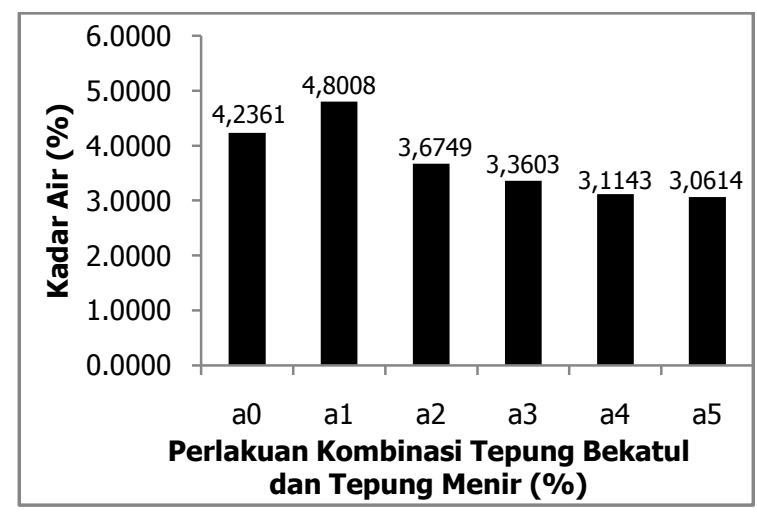

Gambar 1. Grafik Pengaruh Proporsi Tepung Bekatul dan Tepung Menir Terhadap Kadar Air Cookies

Berdasarkan Tabel 2, purata hasil pengamatan kadar air cookies pada masingmasing perlakuan a0, a1, a2, a3, a4 dan a5berturut-turut yaitu 4,2361\%, 4,8008\%, $3,6749 \%, 3,3603 \%, 3,1143$ dan 3,0614\%. Kadar air cookies tertinggi terdapat pada perlakuan a1 yaitu 4,8008\%, sedangkan kadar air terendahterdapat pada perlakuan a5 yaitu $3,0614 \%$.

Dari semua perlakuan a0, a1, a2, a3, a4 dan a5 diketahui bahwa kadar air cookies sudah memenuhi syarat mutu SNI yaitu maksimal 5 persen (SNI, 1992).Pada Gambar1menunjukkan bahwa perlakuan a0 (kontrol) memiliki kadar air yang lebih rendah dibandingkan perlakuan a1 dan lebih tinggi dibandingkan dengan perlakuan a2, a3, a4 dan a5. Selanjutnya Gambar 1 juga menunjukkan kadar air cookies yang diperoleh rata-rata antara 3,0614\%-4,8008\%. Semakin tinggi proporsi penggunaan tepung bekatul dan semikin rendah penggunaan tepung menir maka kadar air dari cookies semakin rendah. Hal ini diduga karena kandungan air yang dimiliki oleh bahan baku. Diketahui bahwa tepung bekatul yang digunakan sebagai bahan baku memiliki kadar air yang lebih rendah dibandingkan tepung menir dan tepung terigu yaknisebesar $5,2477 \%$, sedangkan tepung menir sebesar $11,0789 \%$ dan tepung terigu sebesar $12,3586 \%$.Selain itu semakin rendahnya proporsi tepung menir dalam formulasi maka semakin sedikit pula komponen pati yang dapat menyerap air sehingga air bebas lebih banyak yang teruapkan.Menurut Futkurahman (2012) proses pemanasan menyebabkan terjadinya proses gelatinisasi pati yang mengakibatkan granula pati membengkak karena adanya penyerapan air. Granula pati akan pecah jika telah mencapai batas sehingga menyebabkan terjadi proses penguapan air. Semakin berkurangnya proporsi dari tepung menir menyebabkan daya serap air oleh pati akan semakin menurun.

\section{Kadar Protein}

Berdasarkan Tabel 2 dapat dilihat bahwa proporsi penggunaan tepung bekatul dan tepung menir memberikan pengaruh yang signifikan (berbeda nyata) terhadap kadar protein cookies. Oleh karena itu perlu dilakukan uji lanjut polinomial ortogonal terhadap kadar protein cookies. Hubungan antara proporsi penggunaan tepung bekatul dan tepung menir terhadap kadar protein cookies dapat dilihat pada Gambar2.

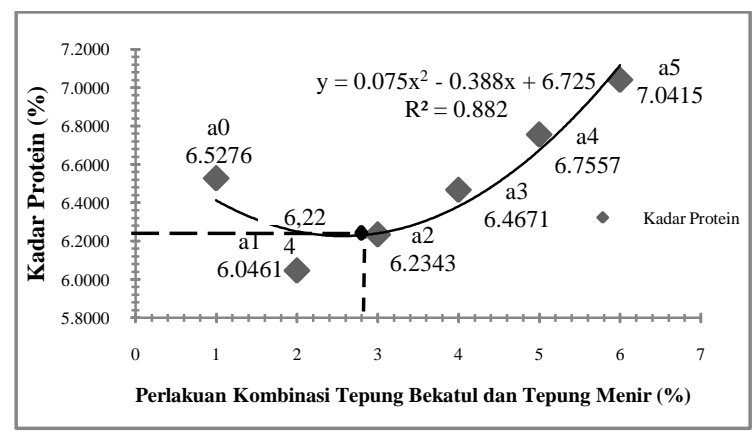

Gambar 2. Grafik Pengaruh Proporsi Tepung Bekatul dan Tepung Menir Terhadap Kadar Protein Cookies

Gambar 2 merupakan grafik proporsi penggunaan tepung bekatul dan tepung menir terhadap kadar protein cookies. Dimana perlakuan a1, a2, a3, a4 dan a5 menunjukkan terjadi peningkatan kadar protein dengan persamaan $y=0,075 x^{2}-0,388 x+6,725$ dengan koefisien determinasi $R^{2}=0,882$. Dari persamaan ini dapat diketahui nilai minimum y (kadar protein) pada nilai minimum $x$ (proporsi tepung bekatul dan menir). Hasil diferensiasi $y=0,075 x^{2}$ $0,388 x+6,725$ adalah $y=0,15 x-0,388$. Titik minimum didapat bila nilai y $=0$. Maka dari persamaan tersebut akan didapatkan nilai minimum $x=2,587$ dan nilai minimum $y=$ 6,224 . Artinya perlakuan dengan titik $x=$ 2,587 mencapai nilai minimum kadar protein sebesar 6,224\%, dimana perlakuan yang mendekati titik ini adalah perlakuan a2 dengan proporsi tepung bekatul $40 \%$ dan tepung menir $60 \%$. Nilai koefisien korelasi yang diperoleh sebesar 0,882 yang termasuk 
katagori sangat kuat.Hal ini menunjukkan korelasi antara penggunaan tepung bekatul dan tepung menir dengan kadar protein cookies sangat kuat. Nilai koefisien determinasi (KD) 0,882 artinya 88,2\% kadar protein cookies dipengaruhi oleh penggunan tepung bekatul dan tepung menir. Semakin tinggi proporsi penggunaan tepung bekatul dan semikin rendah penggunaan tepung menir maka kadar protein dari cookies semakin tinggi.

Dari semua perlakuan a0, a1, a2, a3, a4 dan a5 diketahui bahwa kadarprotein cookies sudah memenuhi syarat mutu SNI yaitu minimal 6 persen (SNI, 1992). Gambar 2 menunjukkan bahwa perlakuan a0 (kontrol) memiliki kadar protein yang lebih tinggi dibandingkan perlakuan a1, a2, a3 dan lebih rendah dibandingkan dengan perlakuan a4 dan a5. Selanjutnya Gambar 2 juga menunjukkan kadar protein cookies yang diperoleh rata-rata antara 6,0461\%-7,0415\%. Hal ini diduga karena kandungan protein yang dimiliki oleh bahan baku. Diketahui bahwa tepung bekatul yang digunakan sebagai bahan baku memiliki kadar protein yang lebih tinggi dibandingkan tepung menir dan tepung terigu yakni sebesar $11,6685 \%$, sedangkan tepung menir sebesar $5,8218 \%$ dan tepung terigu $8,1646 \%$. Sehingga semakin tinggi proporsi penggunaan tepung bekatul dan semikin rendah penggunaan tepung menir maka kadar protein dari cookies semakin tinggi.

\section{Kadar Abu}

Berdasarkan Tabel 2 dapat dilihat bahwa proporsi penggunaan tepung bekatul dan tepung menir memberikan pengaruh yang signifikan (berbeda nyata) terhadap kadar abu cookies. Oleh karena itu perlu dilakukan uji lanjut polinomial ortogonal terhadap kadar protein cookies. Hubungan antara proporsi penggunaan tepung menir dan tepung bekatul terhadap kadar abu cookies dapat dilihat pada Gambar 3.

Gambar 3 merupakan grafik proporsi penggunaan tepung bekatul dan tepung menir terhadap kadar abu cookies. Dimana semua perlakuan a0, a1, a2, a3, a4 dan a5 menunjukkan terjadi peningkatan kadarabu dengan persamaan $y=1,789 x-1,275$ dengan koefisien determinasi $\mathrm{R}^{2}=0,979$. Nilai 1,789 yang menentukan arah regresi linier yang bernilai positif. Hal ini menunjukkan bahwa terdapat hubungan yang positif antara penggunaan proporsi tepung menir dengan tepung bekatul dan kadarabucookies, artinya semakin tinggi penggunaan tepung bekatul maka kadar abucookies semakin meningkat sebesar 1,789. Nilai koefisien korelasi yang diperoleh adalah 0,979 yang termasuk katagori sangat kuat. Hal ini menunjukkan korelasi antara penggunaan tepung bekatul dan kadar abucookies sangat kuat. Nilai koefisien determinasi (KD) 0,979 artinya $97,9 \%$ kadar abucookies dipengaruhi oleh penggunan tepung bekatul. Semakin tinggi proporsi penggunaan tepung bekatul dan semakin rendah penggunaan tepung menir maka kadar abu dari cookies semakin tinggi.

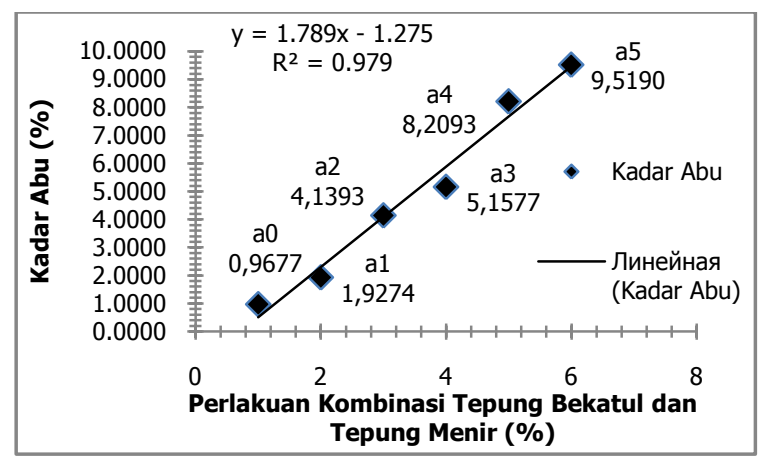

Gambar 3. Grafik Pengaruh Proporsi Tepung Bekatul dan Tepung Menir Terhadap Kadar Abu Cookies

Perlakuan a0 dan a1 diketahui bahwa kadar abucookies sudah memenuhi syarat mutu SNI yaitu maksimal 2 persen (SNI, 1992) sedangkan perlakuan a2, a3, a4 dan a5 memiliki kadar abu yang cukup tinggi jika dibandingkan dengan syarat mutu SNI yakni secara berturut-turut4,1393\%, 5,1577\%, 8,2093 dan 9,5190\%.Gambar 3 menunjukkan bahwa perlakuan a0 (kontrol) memiliki kadarabu yang lebih rendah dibandingkan perlakuan a1, a2, a3, a4 dan a5. Selanjutnya Gambar 3 juga menunjukkan kadar protein cookies yang diperoleh rata-rata antara 0,9677\%-9,5190\%, dimana kadar abu tertinggi pada perlakuan a5. Hal ini diduga karena kandunganabu yang dimiliki oleh bahan baku. Diketahui bahwa tepung bekatul yang digunakan sebagai bahan baku memiliki kadar abu yang lebih tinggi dibandingkan tepung menir dan tepung terigu yakni sebesar 9,5545\%, sedangkan tepung menir sebesar $0,7311 \%$ dan tepung terigu 0,8928\%.Sehingga semakin tinggi proporsi penggunaan tepung bekatul dan semakin rendah penggunaan tepung menir maka kadarabu dari cookies semakin tinggi. Hal ini diduga karena kandungan air bahan yang teruapkan lebih banyak sehingga mineral- 
mineral yang tertinggal pada bahan meningkat. Menurut Sediaoetama (2010) kadar abu menggambarkan banyaknya mineral yang tidak terbakar menjadi zat yang dapat menguap. Kadar abu yaitu sisa yang tertinggal bila suatu sampel bahan makanan dibakar sempurna.

\section{Hasil Analisis Mutu Organoleptik Cookies}

\section{Organoleptik Rasa (Hedonic)}

Berdasarkan hasil pengamatan dan analisis hasil keragaman bahwa proporsi penggunaan tepung menir dan tepung bekatul memberikan pengaruh yang signifikan (berbeda nyata) terhadap mutu organoleptik parameter rasacookies. Berdasarkan hasil penelitian dan analisis data, tingkat kesukaan panelis terhadap rasa dari cookies pada masing-masing perlakuan dapat dilihat pada Gambar 4.

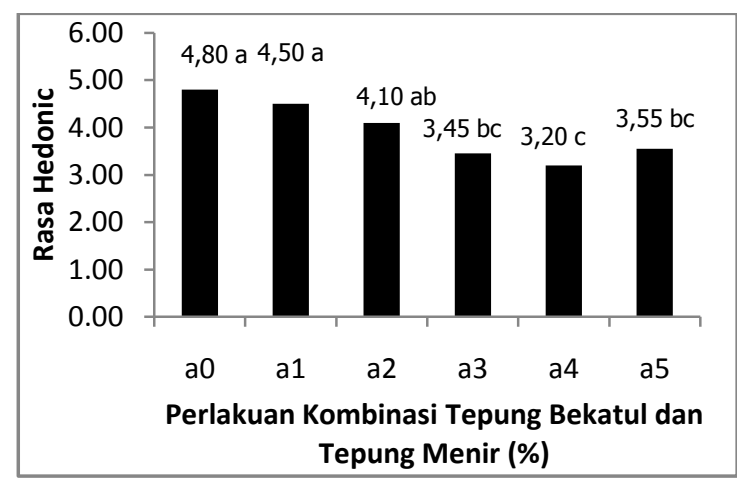

Gambar 4. Grafik Pengaruh Proporsi Tepung Bekatul dan Tepung Menir Terhadap Mutu Organoleptik Parameter Rasa Cookies

Gambar 4menunjukkan bahwa tingkat kesukaan (hedonic) berkisar antara 3,45-4,80 yakni tingkat kesukaan agaksuka sampai sangat suka. Purata hasil pengamatan mutu organoleptik parameter tekstur cookies pada masing-masing perlakuan a0, a1, a2, a3, a4 dan a5 berturut-turut yaitu 4,$80 ; 4,50 ; 4,10$; 3,$45 ; 3,20$ dan 4,55. Dari semua perlakuan a0, a1, a2, a3, a4 dan a5 diketahui bahwa mutu organoleptik parameter rasa cookies sudah memenuhi syarat mutu SNI yaitu memiliki rasa yang normal (SNI, 1992) dan cukup disukai oleh panelis. Gambar 4 menunjukkan bahwa nilai tertinggi diperoleh pada perlakuan a0 (kontrol) yaitu sebesar 4,80 dan merupakan perlakuan yang sangat disukai oleh panelis sedangkan nilai terendah diperoleh pada perlakuan a4 yaitu sebesar 3,20 dan merupakan perlakuan yang agak disukai oleh panelis. Hal ini disebabkan karena kebiasaan panelis yang mengkonsumsi cookies dengan bahan baku tepung terigu. Sehingga untuk perlakuan yang tidak menggunakan tepung terigu yakni menggunakan tepung menir dan tepung bekatul masih ada sebagian kecil panelis yang agak tidak suka. Namun dari perlakuan yang menggunakan proporsi tepung menir dan tepung bekatul yakni perlakuan a1, a2, a3, a4 dan a5 diketahui bahwa nilai tertinggi diperoleh pada perlakuan a1 yaitu sebesar 4,50 dan nilai terendah tetap pada perlakuan a4 yaitu sebesar 3,20.

Berdasarkan nilai purata dan analisis data diperoleh nilai signifikansi untuk setiap perlakuan yaitu, perlakkuan a0 (kontrol) tidak berbeda nyata dengan perlakuan $a 1$, tetapi berbeda nyata dengan perlakuan a2, a3, a4 dan a5.Perlakuan a1 tidak berbeda nyata dengan pelakuan a0, tetapi berbeda nyata dengan perlakuan a2, a3, a4 dan a5.Perlakuan a2 tidak berbeda nyata dengan perlakuan a0, a1 dan a5, tetapi berbeda nyata dengan perlakuan a3 dan a4.Perlakuan a3 tidak berbeda nyata dengan perlakuan a2, a4 dan a5, tetapi berbeda nyata dengan perlakuan a0 dan a1.Perlakuan a4 tidak berbeda nyata dengan perlakuan a3 dan a5, tetapi berbeda nyata dengan perlakuan $\mathrm{a} 0, \mathrm{a} 1$ dan a2. Dan untuk perlakuan a5 tidak berbeda nyata dengan perlakuan a2, a3 dan a4, tetapi berbeda nyata dengan perlakuan a0 dan a1. Dari penjelasan diatas diketahui bahwa perlakuan a0 (kontrol) tidak berbeda nyata dengan perlakuan a1 (tepung menir $70 \%$ : tepung bekatul 30\%) dimana panelis memberikan respon sangat suka. Hal ini menunjukkan bahwa penggunaan tepung menir dan bekatul pada pembuatan cookies memiliki rasa yang tidak berbeda nyata dengan cookies tepung terigu dan sudah dapat diterima oleh panelis.Dan secara keseluruhan dari perlakuan a1, a2, a3, a4 dan a5 rasa dari cookies masih dapat diterima oleh panelis.

\section{Organoleptik Aroma (Hedonic)}

Berdasarkan hasil pengamatan dan analisis hasil keragaman bahwa proporsi penggunaan tepung menir dan tepung bekatul memberikan pengaruh yang signifikan (berbeda nyata) terhadap mutu organoleptik parameter aromacookies. Berdasarkan hasil penelitian dan analisis data, tingkat kesukaan panelis terhadap aroma dari cookies pada masing-masing perlakuan dapat dilihat pada Gambar 5. 


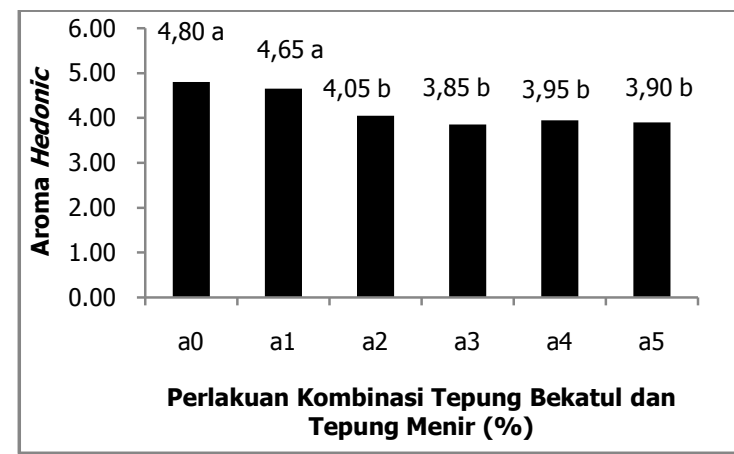

Gambar 5. Grafik Pengaruh Proporsi Tepung Bekatul dan Tepung Menir Terhadap MutuOrganoleptik Parameter Aroma Cookies

Gambar 5menunjukkan bahwa tingkat kesukaan (Hedonic) berkisar antara 3,85-4,80 yakni tingkat kesukaan agak suka sampai sangat suka. Purata hasil pengamatan mutu organoleptik parameter tekstur cookies pada masing-masing perlakuan a0, a1, a2, a3, a4 dan a5 berturut-turut yaitu 4,$80 ; 4,65 ; 4,05$; 3,85; 3,95 dan 3,90. Dari semua perlakuan a0, a1, a2, a3, a4 dan a5 diketahui bahwa mutu organoleptik parameter aromacookies sudah memenuhi syarat mutu SNI yaitu memiliki rasa yang normal (SNI, 1992) dan cukup disukai oleh panelis.Gambar 5 menunjukkan bahwa nilai tertinggi diperoleh pada perlakuan a0 (kontrol) yaitu sebesar 4,80 dan merupakan perlakuan yang sangat disukai oleh panelis sedangkan nilai terendah diperoleh pada perlakuan a3 yaitu sebesar 3,85 dan merupakan perlakuan yang agak disukai oleh panelis. Namun dari perlakuan yang menggunakan proporsi tepung menir dan tepung bekatul yakni perlakuan a1, a2, a3, a4 dan a5 diketahui bahwa nilai tertinggi diperoleh pada perlakuan a1 yaitu sebesar 4,65 dan nilai terendah tetap pada perlakuan a3 yaitu sebesar 3,85 .

Berdasarkan nilai purata dan analisis data diperoleh nilai signifikansi untuk setiap perlakuan yaitu, perlakkuan a0 (kontrol) tidak berbeda nyata dengan perlakuan $a 1$, tetapi berbeda nyata dengan perlakuan a2, a3, a4 dan a5.Perlakuan a1 tidak berbeda nyata dengan pelakuan $\mathrm{a0}$, tetapi berbeda nyata dengan perlakuan a2, a3, a4 dan a5.Perlakuan a2 tidak berbeda nyata dengan perlakuan a3, a4 dan a5, tetapi berbeda nyata dengan perlakuan a0 dan a1.Perlakuan a3 tidak berbeda nyata dengan perlakuan a2, a4dan a5, tetapi berbeda nyata dengan perlakuan a0 dan a1.Perlakuan a4 tidak berbeda nyata dengan perlakuan a2, a3 dan $\mathrm{a} 5$, tetapi berbeda nyata dengan perlakuan a0 dan a1.Dan untuk perlakuan a5 tidak berbeda nyata dengan perlakuan a2, a3 dan a4, tetapi berbeda nyata dengan perlakuan a0 dan a1.Hal ini disebabkan karena sebagian kecil panelis agak suka terhadap aroma bekatul.Bekatul memiliki aroma yang khas sehingga tidak semua panelis menyukainya.Namun dari data yang didapatkan diketahui bahwa sebagian besar dari panelis menyukai aroma khas bekatul.Dari penjelasan diatas diketahui bahwa perlakuan a0 (kontrol) tidak berbeda nyata dengan perlakuan a1 (tepung menir $70 \%$ : tepung bekatul $30 \%$ ) dimana panelis memberikan respon sangat suka. Hal ini menunjukkan bahwa penggunaan tepung menir dan bekatul pada pembuatan cookies memiliki aroma yang tidak berbeda nyata dengan cookies tepung terigu dan sudah dapat diterima oleh panelis. Secara keseluruhan dari perlakuan a1, a2, a3, a4 dan a5 aroma dari cookies masih dapat diterima oleh panelis.

\section{Organoleptik Tekstur (Hedonic dan Scoring)}

Berdasarkan hasil pengamatan dan analisis hasil keragaman bahwa proporsi penggunaan tepung menir dan tepung bekatul memberikan pengaruh yang signifikan (berbeda nyata) terhadap mutu organoleptik parameter teksturcookies secara Hedonic dan Scoring. Oleh karena itu dilakukan uji lanjut beda nyata jujur (BNJ) terhadap mutu organoleptik parameter tekstur cookies secara Hedonic dan Scoring. Berdasarkan hasil penelitian dan analisis data, tingkat kesukaan panelis dan niai scoring terhadap tekstur dari cookies pada masing-masing perlakuan dapat dilihat pada Gambar 6.

Gambar 6 menunjukkan bahwa tingkat kesukaan (Hedonic) berkisar antara 3,45-4,55 yakni tingkat kesukaan agak suka sampai sangat suka. Purata hasil pengamatan mutuorganoleptik parameter teksturcookiespada masing-masing perlakuan $\mathrm{a} 0, \mathrm{a} 1, \mathrm{a} 2, \mathrm{a} 3, \mathrm{a} 4$ dan a5berturut-turut yaitu 4,55; 4,45; 4,10; 3,90; 3,65 dan 3,45. Dari semua perlakuan a0, a1, a2, a3, a4 dan a5 diketahui bahwa tekturcookies sudah memenuhi syarat mutu SNI yaitu memiliki tekstur yang normal (SNI, 1992) dan cukup disukai oleh panelis.Gambar 6 menunjukkan bahwa nilai tertinggi diperoleh pada perlakuan a1 yaitu sebesar 4,55 dan merupakan perlakuan yang sangat disukai oleh panelis sedangkan nilai terendah diperoleh pada perlakuan a5 yaitu sebesar 3,45serta 
merupakan perlakuan yang agak disukai oleh panelis.

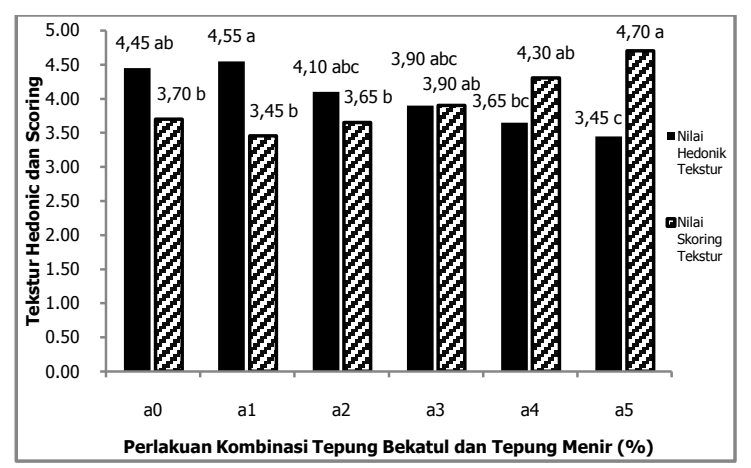

Gambar 6. Grafik Pengaruh Proporsi Tepung Bekatul dan Tepung Menir Terhadap Mutu Organoleptik Parameter Tekstur Cookies

Untuk uji Scoring berkisar antara 3,454,70 (agak renyah sampai sangat renyah). Purata hasil pengamatan mutu organoleptik parameter tekstur cookies pada masingmasing perlakuan a0, a1, a2, a3, a4 dan a5 berturut-turut yaitu 3,70; 3,45; 3,65; 3,90; 4,30 dan 4,70. Dari semua perlakuan a0, a1, a2, a3, a4 dan a5 diketahui bahwa tektur cookies sudah memenuhi syarat mutu SNI yaitu memiliki tekstur yang normal (SNI, 1992).Gambar 6 menunjukkan bahwa nilai tertinggi diperoleh pada perlakuan a5 yaitu sebesar 4,70 sedangkan nilai terendah diperoleh pada perlakuan a1 yaitu sebesar 3,45 .

Berdasarkan tingkat kesukaan (Hedonic) nilai purata dan analisis data diperoleh nilai signifikansi untuk setiap perlakuan yaitu, perlakuan a0 tidak berbeda nyata dengan pelakuan a1, a2, a3 dan a4 tetapi berbeda nyata dengan perlakuan a5.Perlakuan a1 tidak berbeda nyata dengan pelakuan a0, a2 dan a3 tetapi berbeda nyata dengan perlakuan a4 dan a5.Perlakuan a2 dan a3 tidak berbeda nyata dengan semua perlakuan yakni a0, a1, a4 dan a5.Perlakuan a4 tidak berbeda nyata dengan perlakuan a0, a2, a3 dan a5, tetapi berbeda nyata dengan perlakuan a1.Dan untuk perlakuan a5 tidak berbeda nyata dengan perlakuan a2, a3 dan a4, tetapi berbeda nyata dengan perlakuan a0 dan a1.Dari penjelasan diatas diketahui bahwa perlakuan a0 (kontrol) tidak berbeda nyata dengan perlakuan a1 (tepung menir $70 \%$ : tepung bekatul $30 \%$ ) dimana panelis memberikan respon sangat suka. Hal ini menunjukkan bahwa penggunaan tepung menir dan bekatul pada pembuatan cookies memiliki tekstur yang tidak berbeda nyata dengan cookies tepung terigu dan sudah dapat diterima oleh panelis. Secara keseluruhan dari perlakuan a1, a2, a3, a4 dan a5 tekstur dari cookies masih dapat diterima oleh panelis.

Nilai purata dan analisis data uji Scoring diperoleh nilai signifikansi untuk setiap perlakuan yaitu perlakuan a0, a1 dan a2 tidak berbeda nyata dengan pelakuan a3 dan a4 tetapi berbeda nyata dengan perlakuan a5. Perlakuan a3 dan a4 tidak berbeda nyata dengan semua perlakuan yakni a0, a1, a2 dan a5.Dan untuk perlakuan a5 tidak berbeda nyata dengan perlakuan a3 dan a4, tetapi berbeda nyata dengan perlakuan a0, a1 dan a2.Tekstur cookies menunjukkan tekstur yang sangat renyah pada perlakuan a5 dan agak renyah pada perlakuan a1. Hal ini disebabkan karena tingkat kerenyahan dari suatu produk pangan berhubungan dengan kadar air. Hal ini disebabkan karena semakin banyak air yang diuapkan pada saat pemanggangan akan terbentuk rongga-rongga udara sehingga produk yang dihasilkan semakin renyah (Mulyani dkk, 2015).

\section{Organoleptik Warna (Hedonic dan Scoring)}

Berdasarkan hasil pengamatan dan analisis hasil keragaman bahwa proporsi penggunaan tepung menir dan tepung bekatul memberikan pengaruh yang signifikan (berbeda nyata) terhadap mutu organoleptik parameter warna cookiessecara Hedonic dan Scoring. Oleh karena itu dilakukan uji lanjut uji beda nyata jujur (BNJ) terhadap mutu organoleptik parameter warna cookies secara Hedonic dan Scoring. Berdasarkan hasil penelitian dan analisis data, tingkat kesukaan panelis dan nilai scoring terhadap warna dari cookies pada masing-masing perlakuan dapat dilihat pada Gambar 7.

Gambar 7 menunjukkan bahwa tingkat kesukaan (hedonic) berkisar antara 3,75-4,90 yakni tingkat kesukaan agak suka sampai sangat suka. Purata hasil pengamatan mutu organoleptik parameter warnacookies pada masing-masing perlakuan a0, a1, a2, a3, a4 dan a5 berturut-turut yaitu 4,90; 4,80; 4,15; 3,75; 4,10dan 4,30. Dari semua perlakuan a0, a1, a2, a3, a4 dan a5 diketahui bahwa warnacookies sudah memenuhi syarat mutu SNI yaitu memiliki warna yang normal (SNI, 1992) dan cukup disukai oleh panelis.Gambar 7 menunjukkan bahwa nilai tertinggi diperoleh pada perlakuan a0 (kontrol) yaitu sebesar 4,90 dan merupakan 
perlakuan yang sangat disukai oleh panelis sedangkan nilai terendah diperoleh pada perlakuan a3 yaitu sebesar 3,75 serta merupakan perlakuan yang agak disukai oleh panelis. Namun dari perlakuan yang menggunakan proporsi tepung menir dan tepung bekatul yakni perlakuan a1, a2, a3, a4 dan a5 diketahui bahwa nilai tertinggi diperoleh pada perlakuan a1 yaitu sebesar 4,80 dan nilai terendah tetap pada perlakuan a3 yaitu sebesar 3,75 .

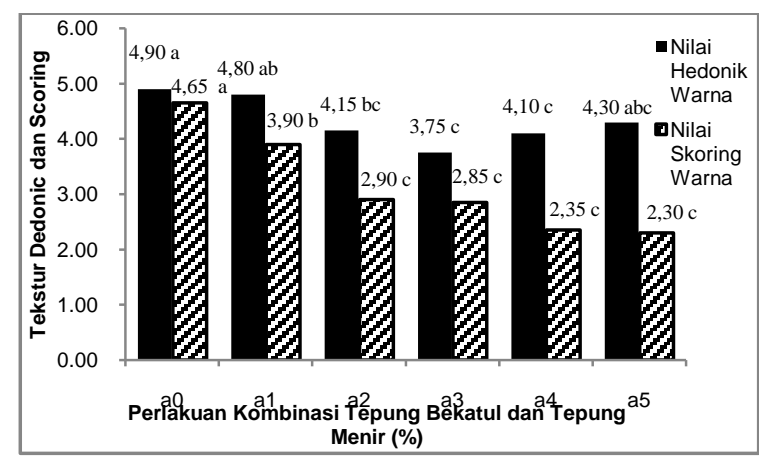

Gambar 7. Grafik Pengaruh Proporsi Tepung Bekatul dan Tepung Menir Terhadap Mutu Organoleptik Parameter WarnaCookies

Untuk uji Scoring berkisar antara 2,30-4,65 (coklat sampai kuning). Purata hasil pengamatan mutu organoleptik parameter warnacookies pada masing-masing perlakuan a0, a1, a2, a3, a4 dan a5 berturut-turut yaitu 4,$65 ; 3,90 ; 2,90 ; 2,85 ; 2,35$ dan 2,30. Dari semua perlakuan a0, a1, a2, a3, a4 dan a5 diketahui bahwa warnacookies sudah memenuhi syarat mutu SNI yaitu memiliki warna yang normal (Badan Standardisasi Nasional, 1992).Gambar 7 menunjukkan bahwa nilai tertinggi diperoleh pada perlakuan a0 yaitu sebesar 4,65 sedangkan nilai terendah diperoleh pada perlakuan a1 yaitu sebesar 2,30.

Berdasarkan tingkat kesukaan (Hedonic) nilai purata dan analisis data diperoleh nilai signifikansi untuk setiap perlakuan yaitu, perlakkuan a0 (kontrol) tidak berbeda nyata dengan perlakuan a1 dan a5 tetapi berbeda nyata dengan perlakuan a2, a3 dan a4.Perlakuan a1 tidak berbeda nyata dengan pelakuan a0, a2 dan a5 tetapi berbeda nyata dengan perlakuan a3 dan a4.Perlakuan a2 tidak berbeda nyata dengan perlakuan yaknia1, a3, a4 dan a5 tetapi berbeda nyata dengan perlakuan a0.Perlakuan a3 dan a4 tidak berbeda nyata dengan perlakuan a2 dan a5 tetapi berbeda nyata dengan perlakuan a0 dan a1.Dan untuk perlakuan a5 tidak berbeda nyata dengan semua perlakuana0, a1, a2, a3, a4 dan a5.Dari penjelasan diatas diketahui bahwa perlakuan a0 (kontrol) tidak berbeda nyata dengan perlakuan a1 (tepung bekatul 30\%:tepung menir 70\%) dimana panelis memberikan respon sangat suka. Hal ini menunjukkan bahwa penggunaan tepung bekatul dan menir pada pembuatan cookies memiliki warna tidak berbeda nyata dengan cookies tepung terigu dan sudah dapat diterima oleh panelis.Dan secara keseluruhan dari perlakuan a1, a2, a3, a4 dan a5 warna dari cookies masih dapat diterima oleh panelis.

Nilai purata dan analisis data uji Scoring diperoleh nilai signifikansi untuk setiap perlakuan. Perlakuan a0 berbeda nyata dengan semua perlakuan.Begitu pula perlakuan a1 berbeda nyata dengan semua perlakuan.Perlakuan a2 tidak berbeda nyata dengan perlakuan a3, a4 dan a5 tetapi berbeda nyata dengan perlakuan a0 dan a1.Begitu pula dengan perlakuan a3 dan a4 tidak berbeda nyata dengan perlakuan a2 tetapi berbeda nyata dengan perlakuan a0 dan a2. Warna cookies menunjukkan semakin banyak proporsi penggunaan tepung bekatul dan semakin sedikit proporsi penggunaan tepung menir maka warna dari cookies akan semakin gelap ditandai dengan nilai skor yang semakin menurun. Hal ini diduga disebabkan oleh warna dasar dari tepung bekatul yang agak gelap (agak kecoklatan).

\section{KESIMPULAN}

Berdasarkan hasil analisis dan pembahasan yang terbatas pada ruang lingkup penelitian ini maka dapat ditarik kesimpulan bahwa proporsi penggunaan tepung tepung dan menir bekatul memberikan pengaruh yang berbeda nyata terhadap parameter kadar protein, kadar abu, uji organoleptik hedonic rasa, aroma, tekstur, warna, uji organoleptik scoring tekstur dan warna cookies, tetapi tidak memberikan pengaruh yang berbeda nyata terhadap parameter kadar air. Semakin tinggi proporsi penggunaan tepung bekatul dan semakin rendah proporsi penggunaan tepung menir maka kadar protein dan kadar abu dari cookies semakin tinggi, namun berbeda dengan kadar air cookies dimana semakin tinggi proporsi penggunaan tepung bekatul dan semakin rendah proporsi penggunaan 
tepung menir kadar air dari cookies semakin rendah. Perlakuan a1 proporsi tepung bekatul $30 \%$ dan tepung menir $70 \%$ dengan kadar air $4,8008 \%$, kadar protein $6,0461 \%$ dan kadar abu $1,9274 \%$, dengan rasa, aroma, tekstur dan warna sangat disukai panelis dimana cookies berwarna cokelat kekuningan dan tekstur agak renyah merupakan perlakuan terbaik pada pembuatan cookies serta telah memenuhi syarat mutu SNI.

\section{DAFTAR PUSTAKA}

Astawan A, dan Febrinda AE. 2010. Potensi dedak dan bekatul beras sebagai ingridient pangan dan produk pangan fungsional. Pangan, 19(1):14-21.

Badan Pusat Statistik. 2016. Buletin Statistik Perdagangan Luar Negeri. Jakarta: Badan Pusat Statistik.

Futkurahman R, Atmaka W, dan Basoto. 2012. Karakteristik sensoris dan sifat fisikokimia cookies dengan subtitusi bekatul beras hitam (Oryza sativa L.) dan tepung jagung (Zae mays L.).J Teknosains Pangan, 1(1): 49-57.

Kadarisman K. 1986. Pengaruh Kelembapan Pangan dan Kadar Air Awal Gabah Varietas Cisadane Selama Penyimpanan Terhadap Perubahan Kadar Air, Rendemen Beras Giling, Beras Kepala,
Beras Patah dan Menir [Skripsi]. Bogor: Fakultas Teknologi Pertanian, IPB.

Mulyani T, Djajati S, \& Rahayu LD. 2015.Pembuatan cookies bekatul (kajian proporsi tepung bekatul dan tepung mocaf) dengan penambahan margarine.J Rekapangan, 9(2):1-8.

Rahayu WP. 1998. Buku Panduan Praktikum Penilaian Organoleptik. IPB Press, Bogor.

Sediaoetama AD. 2010. Ilmu Gizi untuk Mahasiswa dan Profesi Jilid 1. Dian Rakyat, Jakarta.

Standar Nasional Indonesia. 1992. Biskuit.SNI 01-2973-1992. Badan Standardisasi Nasional, Jakarta.

Standar Nasional Indonesia.1992. Cara Uji Makanan dan Minuman.SNI 01-2898192. Badan Standardisasi Nasional, Jakarta.

Standar Nasional Indonesia. 2011. Biskuit. SNI 2973:2011. Badan Standardisasi Nasional, Jakarta.

Widowati S. 2001. Pemanfaatan hasil samping penggilingan padi dalam menunjang sistem agroindustri di pedesaan. Buletin AgroBio, 4(1):33-38. 